\section{ANNUAL DinNER}

The Annual Dinner was held at the Royal College of Obstetricians and Gynaecologists on 7 July 1982. The guests included Dr and Mrs J.D. N. Nabarro, Chairman JCC, Mr and Mrs R.M. Feroze, President of the Royal College of Obstetricians and Gynaecologists, Sir Peter and Lady Tizard, President of the British Paediatric Association, Dr Elizabeth Shore, Deputy Chief Medical Officer at the
DHSS, Lord and Lady Hunter, Professor and Mrs Max Hamilton, Professor Sir Desmond and Lady Pond, and Lord Trefgarne, Joint Parliamentary Under Secretary of State, DHSS.

The Registrar, Professor G. C. Timbury, proposed the toast of 'The Guests' and Lord Trefgarne replied and proposed the toast 'The Royal College of Psychiatrists', to which the President replied.

\title{
Stop Press: The Mental Health (Amendment) Act A Sting in the Tail
}

The Bill has now received Royal Assent and will be implemented in the Autumn of 1983. For a decade the College has been actively concerned with reviewing the 1959 Act and has made detailed responses to the Green Paper 1976 and to the White Paper 1978. When the Bill was introduced into the Lords in 1981 the Public Policy Committee set up a Working Party, chaired by Professor Robert Bluglass, which has laboured mightily to promote improvements in the Bill. We owe this Working Party a great debt. The Act is certainly a more acceptable and practicable piece of legislation as a result of their efforts.

There are swings and roundabouts: we applaud the establishment of a Mental Health Act Commission and we deplore the curious transmogrification of Subnormality and Severe Subnormality to Mental Impairment and Severe Mental Impairment, with its unsatisfactory redefinition of the categories. However, perhaps the most remarkable and certainly unwelcome twist was an unexpected amendment proposed by Mr Terry Davis, MP at the Report Stage in the Commons extending the requirement for a mandatory second opinion in treatments of special concern to 'patients not liable to be detained'. This means that for certain treatments in the future any patient, however willing to have the treatment (understanding its nature and confident in the doctor who proposes it), will have to be reviewed by members of an outside commission before the right to treatment is granted-and it could be refused. This amendment was, however, accepted by the Government. In the week remaining before the final debate in the Lords, the College took steps of the utmost vigour to alert their Lordships and the Government to the retrograde nature of this proposal. To saddle informal patients (or out-patients) with this onerous restriction seemed to run counter to the spirit of the 1959 Act which took steps to liberalize the standing of such patients. All to no avail. An amendment tabled in the Lords to negative this move was eloquently proposed by Lord Mottistone. Other peers agreed with him. A few were anxious lest sending the Bill back to the Commons might lead to its total failure. Nobody except the Government Minister spoke against Lord Mottistone's view. Nevertheless, when the Division bell tolled, the Government carried the day by a large majority. For the moment it will probably apply only to psychosurgery and hormone implants. For the future ...?

K. RAWNSLEY President

\section{Mr and Mrs Geaff Brooks}

After seven years as the College caretakers, Mr and Mrs Geoff Brooks retired in August this year. Staff and officers of the College and members of Council gathered together on 15 October to wish them well. Mr and Mrs Brooks write:

We wish to thank everyone who contributed towards the most acceptable and useful gifts we received on our retirement. It is gratifying to know that our services to the College were appreciated.
We have enjoyed our seven years at the College and will have some happy memories, despite the trials and tribulations that were inevitable in the reorganizing and refurbishment of the College to its present standard. Our good wishes to you all.

We welcome $\mathrm{Mr}$ and Mrs Hugh Farley as the new caretakers. 